\title{
Agricultural Products Trade - the Way to Foster Economic Cooperation between Europe and Asia 10.29023/alanyaakademik.349466
}

\author{
Oksana KIFORENKO
}

PhD, Associate Professor, Uman National University of Horticulture

kiforenko.oksana@gmail.com

\begin{tabular}{|c|c|}
\hline & ABSTRACT \\
\hline $\begin{array}{l}\text { Keywords: } \\
\text { Foreign Trade, } \\
\text { Agricultural } \\
\text { Products, Economic } \\
\text { Relations, Euro- } \\
\text { Asian Cooperation, } \\
\text { FDI } \\
\text { Received: } 06.11 .2017 \\
\text { Accepted: } 15.01 .2018\end{array}$ & $\begin{array}{l}\text { The integration processes in the contemporary world are becoming more } \\
\text { and more active. The said processes are the driving force of the modern } \\
\text { economic development. The Euro - Asian cooperation has become the } \\
\text { necessity that reflects the tendency of the strengthening cooperation between } \\
\text { countries and regions as well as aspiring both Europe and Asia to the } \\
\text { dialogue between each other. } \\
\text { Good relations with both European and Asian countries play an important } \\
\text { role in the politics and economics of Ukraine. The economic situation of } \\
\text { Ukraine cannot be described as a stable one. Together with the improvement } \\
\text { of some indicators characterizing its economic development, some of them } \\
\text { show the decrease in their numerical expression. Taking into account the } \\
\text { said fact, Ukraine is suggested to pay attention to the development of its } \\
\text { relations with Azerbaijan as a country that has a strong economic potential } \\
\text { and is interested in the diversification of its economic relations. } \\
\text { The items that are to be the ways of fostering cooperation in terms of foreign } \\
\text { trade between Ukraine and Azerbaijan in the direction export from Ukraine } \\
\text { - import to Azerbaijan are the ones connected with agriculture, that is } \\
\text { foodstuffs, products of vegetable and animal origin, fats and oils of animal } \\
\text { or vegetable origin. The way to cooperation in the direction export from } \\
\text { Azerbaijan - import to Ukraine lies in the industrial sector of economy, that } \\
\text { is mineral products, miscellaneous articles of base metal, plastic, rubber } \\
\text { and articles and products of chemical industry. } \\
\text { Mutually beneficial cooperation between Ukraine and Azerbaijan will } \\
\text { significantly strengthen the political and economic positions of both } \\
\text { countries on the world arena. }\end{array}$ \\
\hline
\end{tabular}

\section{INTRODUCTION}

The integration processes in the contemporary world are becoming more and more active. The said processes are the driving force of the modern economic development. The rapid economic development of the Asian countries at the end of the twentieth century increased the interest to the said region. That, in turn, gave the impetus to the establishment of the trade and economic relations as well as improvement of the political relations between each other. 
The two continents mentioned above have long-standing cultural and trade relations, that are the basis for the new stage of fostering cooperation between Europe and Asia. Nowadays, Europe and Asia should make more joint efforts for better cooperation in politics, economy, culture etc. The said cooperation aims at uniting the peoples of the two continents and contributing to the strengthening of the integration and friendship between the said parts of the world. The Euro - Asian cooperation has become a necessity that reflects the tendency of strengthening cooperation between countries and regions as well as aspiring both Europe and Asia to the dialogue between each other.

Good relations with both European and Asian countries play an important role in the politics and economics of Ukraine. Taking into account the said fact as well as everything mentioned above, Ukraine is suggested to pay attention to the development of its relations with Azerbaijan as a country has a strong economic potential and is interested in the diversification of its economic relations. In order to do that, a pragmatic course should be focused on, that is on the development of the economic relations between the countries as economic cooperation is one of the main ways of Euro - Asian cooperation concentrated on the trade and investment promotion between Europe and Asia as well as strengthening cooperation in the commercial world.

\section{UKRAINE - CHARACTERISTICS OF THE ECONOMIC DEVELOPMENT}

To further develop the idea developed above, let's describe the state of the economic development of Ukraine. In order to analyze the level of the economic development of any country, one should consider certain indicators that characterize the patterns of the national economy functioning of the country under research. These indicators include: gross domestic product (further - GDP), GDP per capita, inflation rate, the amount of the direct foreign investment (further - FDI) and others. The analysis of the economic development of Ukraine will be started from the analysis of the GDP of the country, because this indicator is one of the most accurate ones to show the level of the economic development of any country. The dynamics of the GDP of Ukraine can be followed in Figure 1

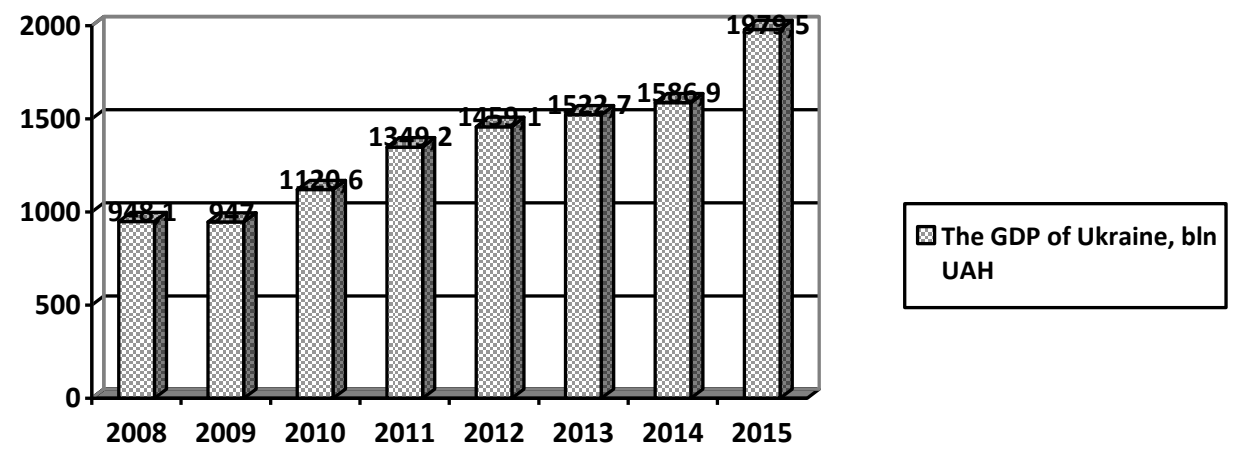

Figure 1. The GDP of Ukraine, bln UAH

Source: author's elaboration on the basis of the data from the State Statistic Service of Ukraine ${ }^{1}$

Analyzing the figure given above, we see that in 2009 the GDP of Ukraine was $0.2 \%$ lower than in 2008. In fact, in 2009 Ukraine's got the lowest amount of GDP in the period under

\footnotetext{
${ }^{1}$ Ukraine in Figures [Electronic resource] // Access mode: https://ukrstat.org/uk/druk/publicat/kat_u/publ1_u.htm.
} 
research. The explanation of the said situation can be the influence of the global financial crisis on the economic development of Ukraine. The matter is that the globalization process is so overall nowadays that it is practically impossible for a country to exist and develop without being influenced by the global economic processes. After the year 2009 the dynamics of GDP of Ukraine has a clear upward trend - in 2010 it was $18.3 \%$ higher than in the previous year, in $2011-20.4 \%$ and in $2012-8.1 \%$ higher than in the year before. In 2013 the upward trend was not broken and was marked by the increase of the GDP of the country of $4.4 \%$ if compared to that of 2012. In 2014 the GDP of Ukraine increased $4.2 \%$ and in $2015-24.7 \%$ if compared to that of the previous year. In 2015 the amount of the GDP of the country was the biggest in the period under research. But if we take a look at the change of the GDP of Ukraine in the constant prices, the situation ceases to be so "rosy" - in 2014 the said indicator decreased $6.6 \%$ and in $2015-9.9 \%$ if compared to that of the previous year ${ }^{2}$.

Since the objective of any state functioning is the welfare of its citizens, let's consider the dynamics of the GDP of Ukraine per capita according to Figure 2.

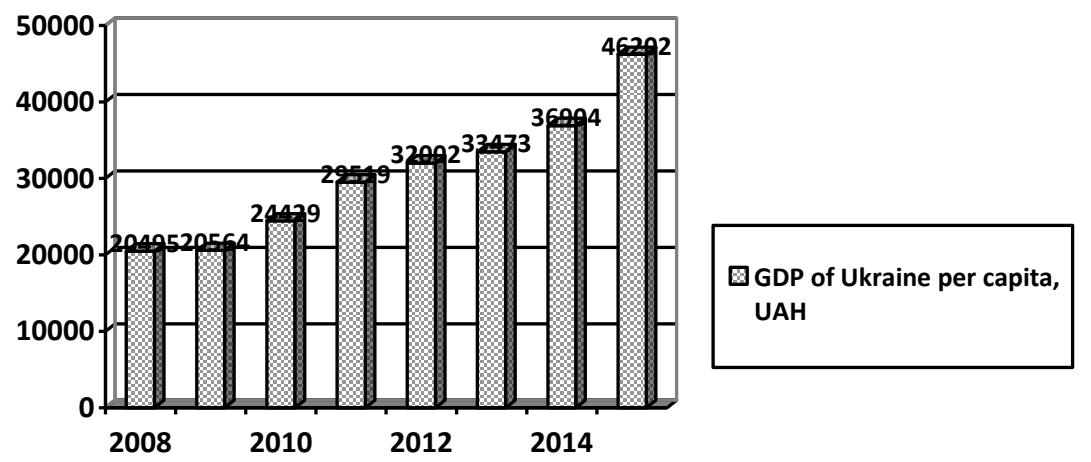

Figure 2. The GDP of Ukraine per capita, UAH

Source: author's elaboration on the basis of the data from the State Statistic Service of Ukraine ${ }^{3}$

Having analyzed the data in the figure given above, we see the clear upward trend in the dynamics of the GDP of Ukraine per capita in the period under research. The positive changes in the GDP of Ukraine per capita are as follows - in 2009 it was $0.3 \%$, in $2010-19$ $\%$, in $2011-21 \%$, in $2012 \%-8 \%$, in $2013-5 \%$, in $2014-10 \%$ and in 2015 the GDP of Ukraine per capita was $25 \%$ higher than in the previous year. So, the lowest level of GDP of Ukraine per capita can be ob served in 2008 and the highest - in 2015.

While analyzing the level of the economic development of Ukraine, it is necessary to mention the amount of FDI into the economy of the country. The dynamics of the said investment into the economy of Ukraine can be followed in Figure 3.

\footnotetext{
${ }^{2}$ Ukraine - 2015 [Electronic resource] // Access mode: https://ukrstat.org/uk/druk/publicat/kat_u/publ1_u.htm].

${ }^{3}$ Ukraine in Figures [Electronic resource] // Access mode: https://ukrstat.org/uk/druk/publicat/kat_u/publ1_u.htm.
} 

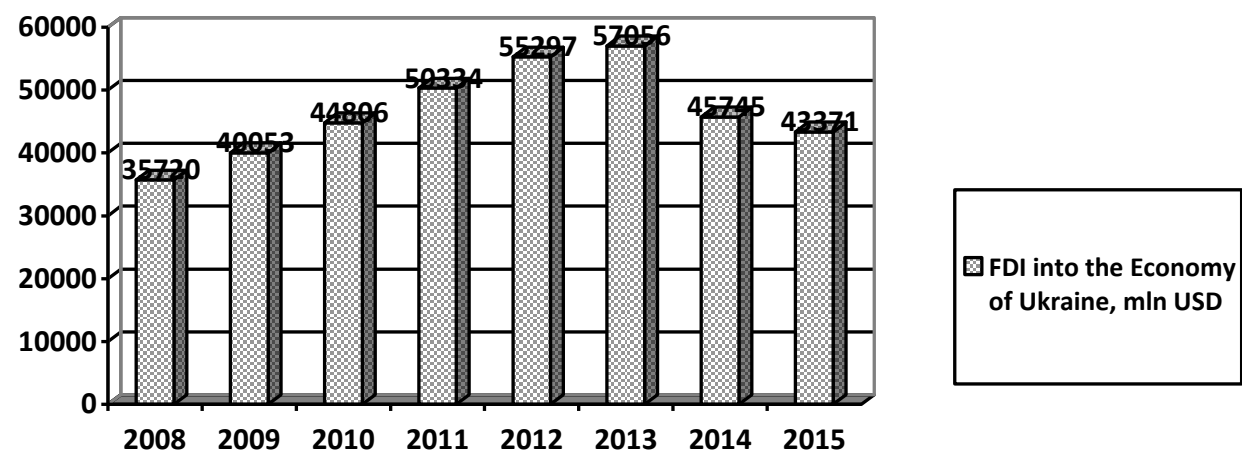

Figure 3. The FDI into the Economy of Ukraine, mln USD

Source: author's elaboration on the basis of the data from the State Statistic Service of Ukraine ${ }^{4}$

According to Figure 3, there is no one clear trend in the dynamics of FDI into the economy of Ukraine. From 2008 to 2013 including, the dynamics of FDI showed the upward trend. In fact, the year 2008 was marked by the lowest amount of FDI invested into the economy of Ukraine. In 2009 the direct foreign investment was $4332 \mathrm{mln}$ USD or $12 \%$ higher than in the previous year. In the year 2010 the amount of FDI was $4753 \mathrm{mln}$ USD or $12 \%$, in $2011-$ $5528 \mathrm{mln}$ USD or $12.3 \%$, in $2012-4963 \mathrm{mln}$ USD or $10 \%$ and in $2013-1759 \mathrm{mln}$ USD or $3.2 \%$ higher than in the previous year. The year 2013 was the last one in the period under research that showed the positive tendency in the dynamics of FDI into the economy of Ukraine and the year with the highest amount of FDI invested into the economy of the country. The next two years - 2014 and 2015 - were marked with the decrease in the amount of the said investment - in 2014 - by 11311 mln USD or approximately $20 \%$ and in 2015 by $2374 \mathrm{mln}$ USD or $5.2 \%$ if compared to the previous year. The explanation of such a state of affairs may be the unstable political situation and the changes in the financial sector of the economy of the country which make the foreign investors be more careful while investing into the Ukrainian economy.

The structure of direct foreign investment into the economy of Ukraine according to economic activities can be followed in Figure 4

\footnotetext{
${ }^{4}$ Ukraine in Figures [Electronic resource] // Access mode: https://ukrstat.org/uk/druk/publicat/kat_u/publ1_u.htm.
} 


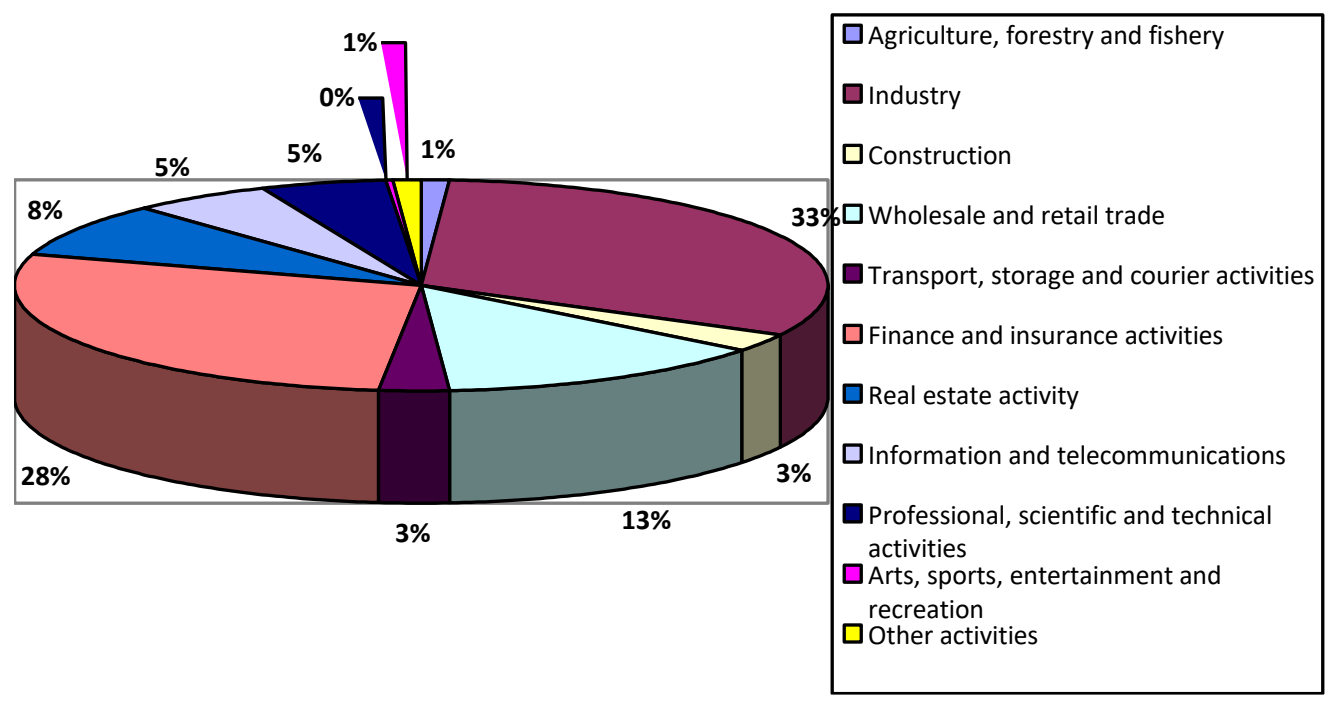

Figure 4. The Structure of Direct Foreign Investment into the Economy of Ukraine According to Economic Activities, \%

Source: author's elaboration on the basis of the data from the State Statistic Service of Ukraine ${ }^{5}$

As it can be seen from the figure presented above, the biggest amount of FDI is directed into industry (33\%), the second place is taken by finance and insurance activity (28\%) and the third - by wholesale and retail trade $(13 \%$ of the total amount of direct foreign investment into the economy of Ukraine).

Ten countries that are the biggest investors into the economy of Ukraine and the dynamics of their investment can be followed in Table 1.

\footnotetext{
${ }^{5}$ Ukraine [Electronic resource] // Access mode: https://ukrstat.org/uk/druk/publicat/kat_u/publ1_u.htm.
} 
Table 1: The FDI into the Economy of Ukraine from Ten Biggest Investors, mln USD

\begin{tabular}{|c|c|c|c|c|c|c|c|c|c|c|}
\hline \multirow[t]{2}{*}{ № } & \multirow[t]{2}{*}{$\begin{array}{c}\text { Countr } \\
y\end{array}$} & \multicolumn{6}{|c|}{ The Amount of FDI into the Economy of Ukraine } & \multicolumn{2}{|c|}{$\begin{array}{l}\text { Ratio of } 2015 \text { to } \\
2009 \text {, mln USD }\end{array}$} & \multirow{2}{*}{$\begin{array}{c}\text { Ratio of } \\
2015 \text { to } \\
2009, \%\end{array}$} \\
\hline & & 2009 & 2010 & 2011 & 2012 & 2013 & 2014 & 2015 & & \\
\hline 1 & Cyprus & $\begin{array}{c}9005 . \\
3 \\
\end{array}$ & $\begin{array}{c}10044 \\
.9 \\
\end{array}$ & 13355.2 & 17748.6 & 18978.5 & $\begin{array}{c}1370 \\
7.6\end{array}$ & 11744.9 & $\begin{array}{c}2739 \\
.6\end{array}$ & 30.4 \\
\hline 2 & $\begin{array}{l}\text { The } \\
\text { Nether } \\
\text {-lands }\end{array}$ & $\begin{array}{c}3954 . \\
5\end{array}$ & $\begin{array}{c}4683 . \\
3\end{array}$ & 4898.0 & 5188.5 & 5543.7 & $\begin{array}{c}5219 . \\
1\end{array}$ & 5610.7 & $\begin{array}{c}1656 \\
.2\end{array}$ & 41.9 \\
\hline 3 & $\begin{array}{l}\text { Germa } \\
\text { ny }\end{array}$ & $\begin{array}{c}6601 . \\
9\end{array}$ & $\begin{array}{c}7083 . \\
0\end{array}$ & 7391.8 & 6120.9 & 6202.4 & $\begin{array}{c}5684 . \\
7\end{array}$ & 5414.3 & $\begin{array}{c}- \\
1187 \\
.6\end{array}$ & -18 \\
\hline 4 & $\begin{array}{l}\text { Russia } \\
\mathrm{n} \\
\text { Federa } \\
\text { tion }\end{array}$ & $\begin{array}{c}2566 . \\
4\end{array}$ & $\begin{array}{c}3403 . \\
2\end{array}$ & 3600.4 & 3793.0 & 3902.8 & $\begin{array}{c}2715 . \\
9\end{array}$ & 3392.1 & $\begin{array}{c}825 \\
7\end{array}$ & 32.2 \\
\hline 5 & $\begin{array}{l}\text { Austri } \\
\mathrm{a}\end{array}$ & $\begin{array}{c}2605 . \\
2\end{array}$ & $\begin{array}{c}2731 \\
4\end{array}$ & 3418.8 & 3402.6 & 3178.8 & $\begin{array}{c}2513 . \\
6\end{array}$ & 2402.4 & $\begin{array}{c}- \\
202 . \\
8\end{array}$ & -7.8 \\
\hline 6 & $\begin{array}{l}\text { Great } \\
\text { Britain }\end{array}$ & $\begin{array}{c}2307 . \\
5\end{array}$ & $\begin{array}{c}2287 . \\
1\end{array}$ & 2593.4 & 2553.6 & 2768.2 & $\begin{array}{c}2153 . \\
4\end{array}$ & 1852.5 & -455 & -19.7 \\
\hline 7 & $\begin{array}{l}\text { Virgin } \\
\text { Islands }\end{array}$ & $\begin{array}{c}1342 . \\
7\end{array}$ & $\begin{array}{c}1451 . \\
5\end{array}$ & 1666.0 & 2007.6 & 2275.9 & $\begin{array}{c}1988 . \\
3\end{array}$ & 1798.9 & $\begin{array}{c}456, \\
2\end{array}$ & 34 \\
\hline 8 & France & $\begin{array}{c}1630 . \\
8\end{array}$ & $\begin{array}{c}2368 . \\
1\end{array}$ & 2260.4 & 1766.6 & 1740.9 & $\begin{array}{c}1615 . \\
0\end{array}$ & 1528.1 & $\begin{array}{c}- \\
102 . \\
7\end{array}$ & -6.3 \\
\hline 9 & $\begin{array}{l}\text { Switze } \\
\text { rland }\end{array}$ & 796.4 & 862.3 & 947.7 & 1105.9 & 1351.0 & $\begin{array}{c}1391 . \\
5\end{array}$ & 1364.2 & $\begin{array}{c}567 . \\
8\end{array}$ & 71.3 \\
\hline $\begin{array}{l}1 \\
0\end{array}$ & Italy & 982.0 & 980.6 & 975.1 & 1027.6 & 1210.2 & 997.1 & 972.4 & -9.6 & -1 \\
\hline
\end{tabular}

Source: author's calculations on the basis of the data from the State Statistic Service of Ukraine ${ }^{6}$

The data given in Table 1 allow us make the following conclusions - five countries out of ten biggest investors increased their investment into the economy of Ukraine in 2015 if compared to that of 2009: Cyprus - by $2739.6 \mathrm{mln}$ USD (30.4\%), the Netherlands - by $1656.2 \mathrm{mln}$ USD (41.4\%), the Russian Federation - by 825.7 mln USD (32.2 \%), Virgin Islands - by $456.2 \mathrm{mln}$ USD (34 \%) and Switzerland - by $567.8 \mathrm{mln}$ USD (71.3\%). That, in turn, testifies to the improvement of the investment climate of the country that attracts foreign investors. The factors that improve Ukraine's image in the eyes of the foreign investors include: favorable geographical location of the country, the availability of cheap work force, the availability of quality raw materials and resources, big market for goods and services and others.

But, together with the countries that increased their investment into the Ukrainian economy, there are those that decreased the amount of the said investment. There are five of them out of

${ }^{6}$ Ukraine in Figures [Electronic resource] // Access mode: https://ukrstat.org/uk/druk/publicat/kat_u/publ1_u.htm. 
the ten biggest investors presented in Table 1 - Germany decreased the investment into the economy of Ukraine by $1187.6 \mathrm{mln}$ USD (18 \%), Austria - by $202.8 \mathrm{mln}$ USD (7.8 \%), Great Britain - by 455 mln USD (19.7\%), France - by $102.7 \mathrm{mln}$ USD (6.3 \%) and Italy - by $9.6 \mathrm{mln}$ USD (1\%) in 2015 if compared to that of 2009. The following factors can be considered as those worsening the investment attractiveness of Ukraine for foreign investors: the instability of the currency of the country, the instability of the political situation in the country, high inflation rate, the instability of both domestic and foreign currency markets.

So, one of the main tasks for Ukraine nowadays is to make the Ukrainian economy more attractive for foreign investors as the increase of FDI positively affects the balance of payments, the level of employment in the country and contribute to its further economic development.

\section{EXPORT FROM UKRAINE - IMPORT TO AZERBAIJAN}

One of the ways to improve an unstable economic situation of a country is to increase the amount of its exports as it usually provides the country with foreign currency, stabilizes its positions on foreign markets, creates new jobs etc. That's why the next point of the research started above is the analysis of the Ukrainian goods exports dynamics (Figure 5).

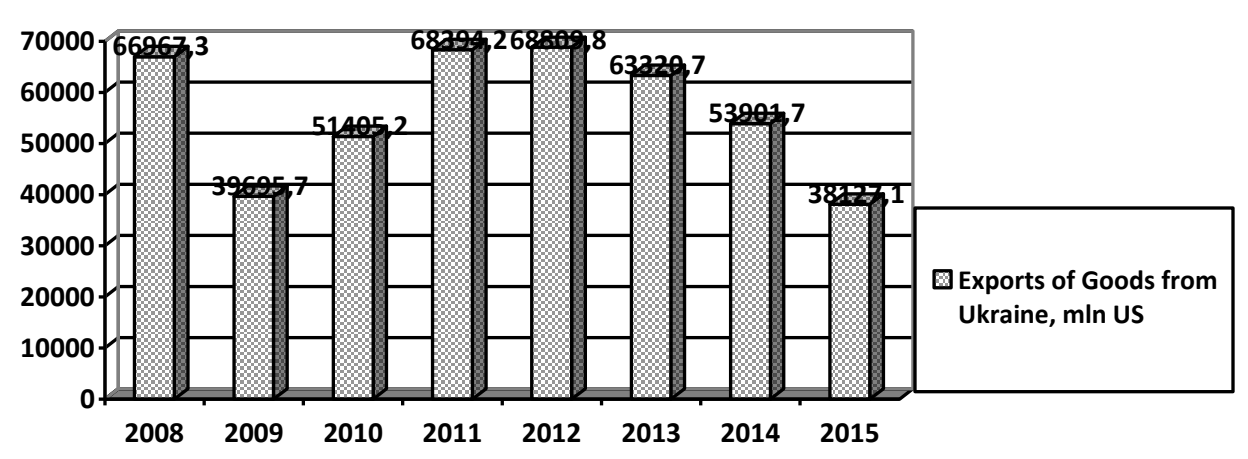

Figure 5. The Dynamics of Goods Exports from Ukraine, mln USD

Source: author's elaboration on the basis of the data from the State Statistic Service of Ukraine ${ }^{7}$

As it can be seen from the figure given above, the dynamics of the exports of goods from Ukraine doesn't have one clear tendency - it's very changeable. In 2009 the amount of the exports dropped $27271,6 \mathrm{mln}$ USD or $40.7 \%$ if compared to that of 2008 . The explanation of that may be the negative influence of the world financial crisis. But after that the tendency changed to the opposite one showing the upward trend in the amount of goods exports from Ukraine in the period from 2009 to 2012 including. The said indicator increased by 11709,5 mln USD or $29.5 \%$ in 2010, in 2011 - by 16989 mln USD or $33 \%$ and in 2012 - by 405.6 mln USD or $0.6 \%$ if compared to the previous year. But after the year 2012 the amount of exports from Ukraine started decreasing to the end of the period under research. In 2013 the said indicator decreased by $5459.1 \mathrm{mln}$ USD or $8 \%$, in 2014 - by $9419 \mathrm{mln}$ USD or $15 \%$ and in 2015 - by 15774.6 mln USD or $29 \%$ if compared to that of the previous year.

\footnotetext{
${ }^{7}$ Commodity Structure of Foreign Trade [Electronic resource] // Access mode: https://ukrstat.org/uk/operativ/operativ2015/zd/tsztt/tsztt_u/tsztt1315_u.htm.
} 
In 2015 Ukraine conducted foreign trade operations with 217 countries. The biggest amounts of goods from Ukraine were exported to the Russian Federation (12.7\% of the total amount), Turkey $(7.3 \%)$, China $(6.3 \%)$, Egypt $(5.5 \%)$, Italy (5.2 \%), Poland (5.2 \%), India (3.8 \%) and Germany $(3.5 \%)^{8}$.

If we take a look at the structure of the exports from Ukraine in terms of the groups of countries Ukraine exports its goods to, we'll see the following pattern (Figure 6)

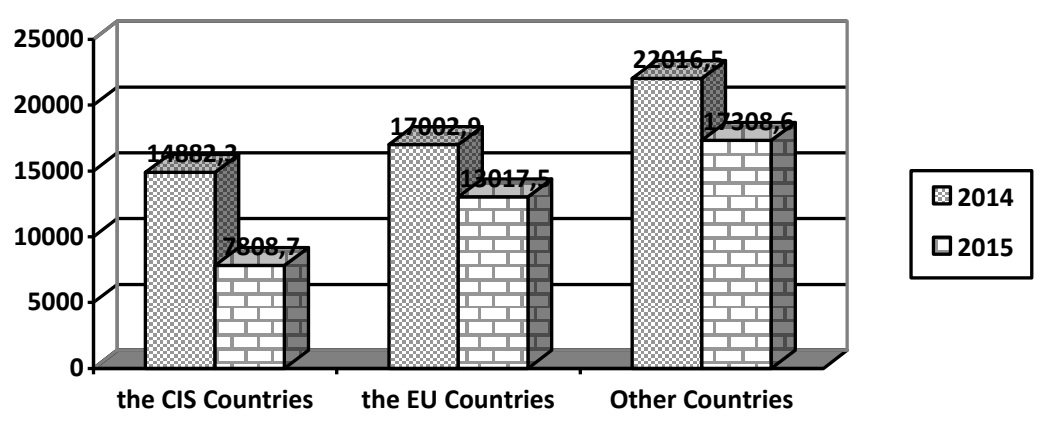

Figure 6. The Structure Dynamics of the Goods Exports from Ukraine, mln USD

Source: author's elaboration on the basis of the data from the State Statistic Service of Ukraine ${ }^{9}$

It's hard not to notice that in 2015 Ukrainian exports decreased to all the groups of countries depicted in Figure 6: to the CIS countries - by 7073, $6 \mathrm{mln}$ USD or $47.5 \%$, to the EU countries - by $3985.4 \mathrm{mln}$ USD or $23.4 \%$ and to the other countries - by $4707.9 \mathrm{mln}$ USD or $21.4 \%$ if compared to that of the year 2014 .

In such a situation, one can either search for new trade partners or have a closer look at the existing ones, seeking new ways of cooperation for the mutual benefits of both countries. Such a partner for Ukraine, which is worth paying attention at, is Azerbaijan, though this country is not among the closest partners of Ukraine in terms of foreign trade (e.g. in 2015 Azerbaijan took the fifth place among the CIS countries in terms of the goods trade with Ukraine). In this paper the new ways to foster cooperation between Ukraine and Azerbaijan will be tried to find. But first of all, let's analyze the present state of affairs between the said two countries in terms of economic cooperation in general and trade in goods in particular. The dynamics of the goods and services trade turnover between Ukraine and Azerbaijan can be followed in Figure 7

\footnotetext{
${ }^{8}$ Ukraine's Foreign Trade in Goods [Electronic resource] // Access mode: https://ukrstat.org/uk/operativ/operativ2015/zd/tsztt/tsztt_u/tsztt1315_u.htm.

${ }^{9}$ Ukraine's Foreign Trade in Goods [Electronic resource] // Access mode: https://ukrstat.org/uk/operativ/operativ2015/zd/tsztt/tsztt_u/tsztt1315_u.htm.
} 


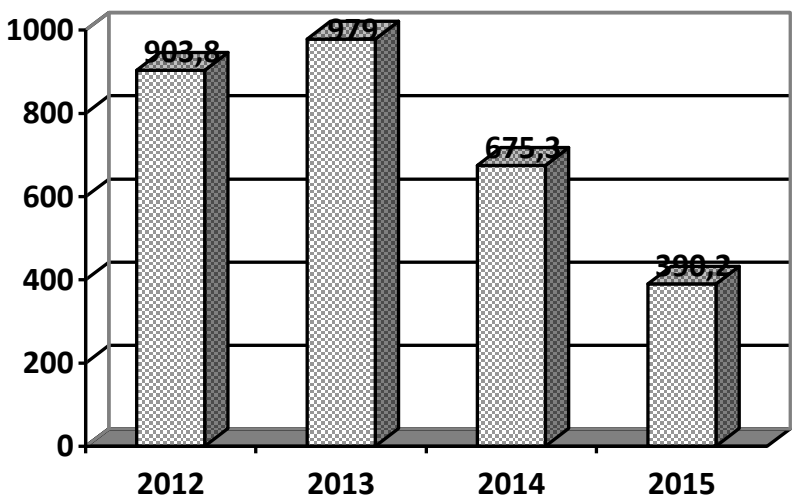

$\square$ Goods and Services Turnover Between Ukraine and

Azerbaijan, mln US

Figure 7. The Dynamics of the Goods and Services Trade Turnover Between Ukraine and Azerbaijan, mln USD

Source: author's elaboration on the basis of the data from the Embassy of Ukraine in the Republic of Azerbaijan ${ }^{10}$

In the figure presented above, no one single tendency can be seen. In 2013 the goods and services trade turnover was $75.2 \mathrm{mln}$ USD or $8.3 \%$ bigger than in 2012. But in the following year the tendency changed to the downward one showing the decline in the said indicator by 303.7 mln USD or $31 \%$ if compared to that of 2013. In the year 2015 the decline was even bigger and comprised 285.1 mln USD or $42.2 \%$.

The dynamics of the goods exports from Ukraine to Azerbaijan can be followed according to Figure 8

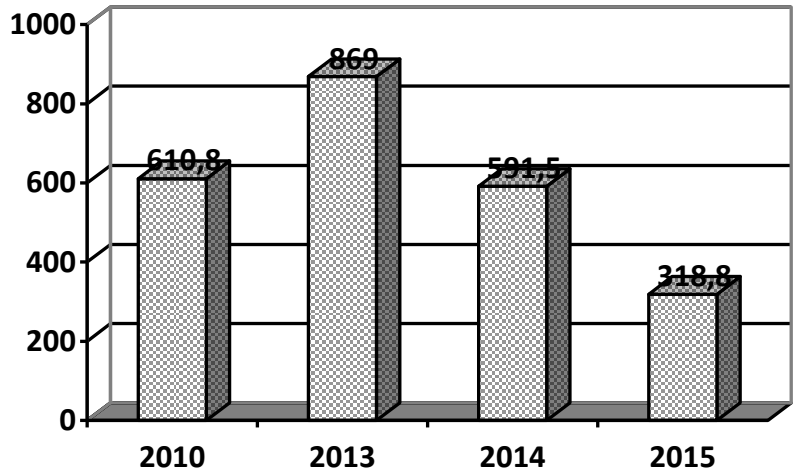

Exports of Goods from Ukraine to Azerbaijan, mln USD

Figure 8. The Dynamics of the Goods Exports from Ukraine to Azerbaijan, mln USD Source: author's elaboration on the basis of the data from the State Statistic Service of Ukraine ${ }^{11}$

\footnotetext{
${ }^{10}$ Trade and Economic Relations of Ukraine and Azerbaijan [Electronic resource] // Access mode: http://azerbaijan.mfa.gov.ua/ru/ukraine-az/trade.

${ }^{11}$ Ukraine's Foreign Trade in Goods [Electronic resource] // Access mode: https://ukrstat.org/uk/operativ/operativ2015/zd/tsztt/tsztt_u/tsztt1315_u.htm.
} 
The dynamics of the goods exports from Ukraine to Azerbaijan is very much like the dynamics of the goods and services trade turnover between the two countries. The increase by $258.2 \mathrm{mln}$ USD or $42.3 \%$ is shown in 2013 if compared to that of 2010. But after the year 2013 the amount of goods exported from Ukraine to Azerbaijan decreased continually: in 2014 - by $277.5 \mathrm{mln}$ USD or $32 \%$ and in 2015 - by $272.7 \mathrm{mln}$ USD or $46 \%$ if compared to that of the previous year.

In 2015 the main items of the Ukrainian exports to Azerbaijan were: ferrous metals (decreased by $73.9 \%$ if compared to the previous year) and ferrous metals products (decreased by $34.2 \%$ ) - together make $25.8 \%$; tobacco and manufactured tobacco substitutes - $14.4 \%$ (decreased by $29.3 \%$ ); paper and cardboard - $4.9 \%$ (decreased by $34.8 \%$ ); sugar and sugar confectionery $-4.5 \%$ (decreased by $23.9 \%$ ); products from grain $-4.5 \%$ (decreased by $37.1 \%$ ); wood and wood products $-4.4 \%$ of the total exports volume from Ukraine to Azerbaijan (decreased by $50.2 \%$ ).

The explanation of such a decrease in the amount of goods exports from Ukraine to Azerbaijan may be the decrease in the exports of ferrous metals and their products because of the anti - terrorist operation in the eastern regions of Ukraine where the main industrial enterprises functioning in the metallurgical sector were situated. To further develop the thought mentioned above, it's necessary to add that the basis of the commodity structure of the Ukrainian exports in general constituted non-precious metals and products from them $(24.8 \%)$, products of plant origin $(20.9 \%)$, mechanical and electrical mechanisms $(10.3 \%)$, fats and oils of animal or plant origin $(8.7 \%)$, mineral products $(8.1 \%)$, ready food products $(6.5 \%)$, chemicals and related industries products $(5.6 \%)$.

In order to find the fields of mutual intersect in terms of foreign trade, let's analyze the import structure of Azerbaijan (Figure 9).

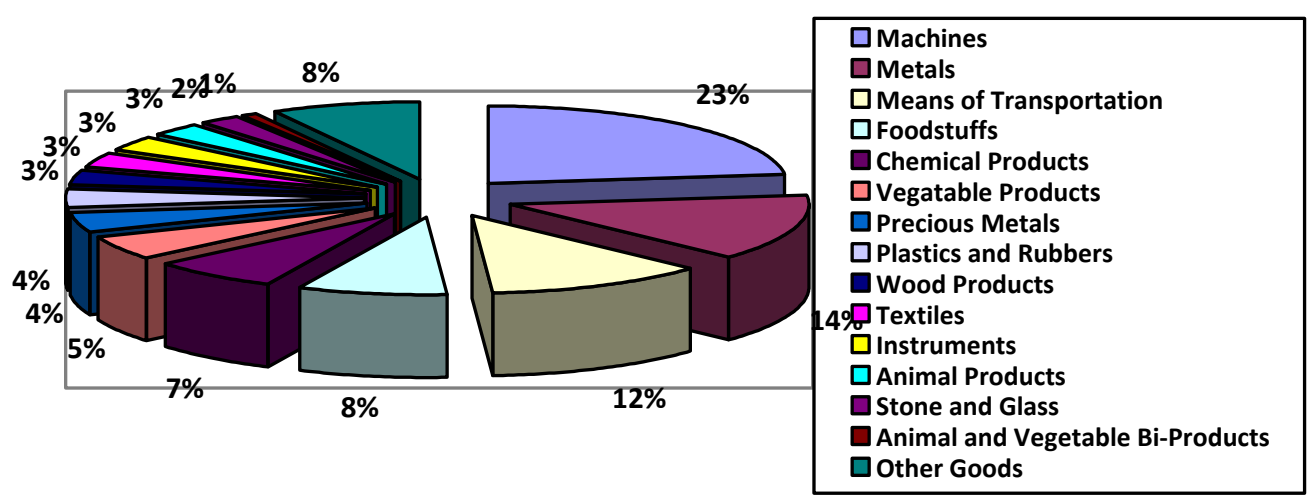

Figure 9. The Structure of Goods Import to Azerbaijan, \%

Source: author's own elaboration on the basis of the data ${ }^{12}$

The analysis of the data in the figure given above allows us make the following conclusions: the first place according to the share in the total amount of import is taken with machines and mechanisms $(23 \%)$, the second - with metals and products made of them $(14 \%)$ and the third - with the means of transportation $(12 \%)$. What is also worth paying attention at is that $8 \%$ of the total amount of the import into Azerbaijan is taken with foodstuffs, $5 \%$ - with

\footnotetext{
${ }^{12}$ Azerbaijan [Electronic resource] // Access mode: http://atlas.media.mit.edu/en/profile/country/aze/\#Imports.
} 
plant products, $3 \%$ - with animal products and $1 \%$ is taken with animal and vegetable biproducts. The main exporters to Azerbaijan according to their share in the total amount of import into Azerbaijan are Russia, Turkey, Great Britain, China, Germany, the USA, Ukraine, Italy, Kazakhstan and Brazil ${ }^{13}$.

The evaluation of the import amount of the agricultural production, gives us the following results: foodstuffs take $8 \%$ of the whole amount of Azerbaijan import, including - rolled tobacco $(2,3 \%)$, raw sugar $(1,4 \%)$, chocolate $(0,75 \%)$, baked goods $(0,62 \%)$ and others. The main exporters of foodstuffs to Azerbaijan are Russia, Ukraine, Brazil and Turkey. The next item of agricultural import under analysis is vegetable products (5\% of the total amount of Azerbaijan import), including wheat $(2,8 \%)$, tea $(0,32 \%)$, corn $(0,22 \%)$, barley $(0,18 \%)$, potatoes $(0,16 \%)$, rice $(0,155)$, sunflower seeds $(0,052 \%)$ and others. The main exporters of vegetable products to Azerbaijan are Russia, Kazakhstan, Sri Lanka, Turkey, Netherlands, Pakistan, India and Italy. The structure of the animal products import (3\%) to Azerbaijan is as follows: butter $(0,66 \%)$, bovine $(0,36 \%)$, poultry meat $(0,26 \%)$, cheese $(0,25 \%)$, sheep and goats $(0,14 \%)$ and others. The main exporters of the animal products to Azerbaijan are New Zealand, Georgia, Ukraine, Brazil, the USA, Turkey, Germany and Russia. As for animal and vegetable bi-products $(1 \%)$, the structure of this import item includes seed oils $(0,24 \%)$, palm oil $(0,19 \%)$, margarine $(0,16 \%)$, other pure vegetable oils $(0,12 \%)$ and others. The main exporters of animal and vegetable bi-products to Azerbaijan are Russia, Indonesia, Ukraine and the USA ${ }^{14}$.

So, the items that are to be the ways of fostering cooperation in terms of foreign trade between Ukraine and Azerbaijan in the direction export from Ukraine - import to Azerbaijan are the ones connected with agriculture, that is foodstuffs, products of vegetable and animal origin, fats and oils of animal or vegetable origin. They are the items that take a big share in the amount of goods exports from Ukraine and, at the same time, the big shares in the amount of goods imports to Azerbaijan.

In order to concretize the agricultural goods that are of mutual interest for both countries in terms of trade, let's analyze the agriculture functioning of Ukraine. Agriculture is an important sector of the economy of Ukraine. The share of agriculture in the GDP of Ukraine was $10.4 \%$ in 2015 (0.4\% more than in the previous year) ${ }^{15}$. The dynamics of the gross agricultural output of Ukraine can be followed in Figure 10

\footnotetext{
${ }^{13}$ Analytical Information on Foreign Trade Statistics of the Republic of Azerbaijan [Electronic resource] // Access mode:

http://www.ved.gov.ru/files/images/country/Azerbaijan/2015/Analytical\%20information\%20on\%20foreign\%20trade \%20statistics\%20of\%20the\%20Republic\%20of\%20Azerbaijan\%20in\%202014.pdf.

${ }^{14}$ Azerbaijan Import [Electronic resource] // Access mode: http://atlas.media.mit.edu/en/profile/country/aze/\#Imports.

${ }^{15}$ AgroPolit.com[Electronic resource] // Access mode: https://agropolit.com/news/172-ukrayina-na-8-mistsi-ureytingu-nayrozvinutishih-agrarnih-krayin.
} 


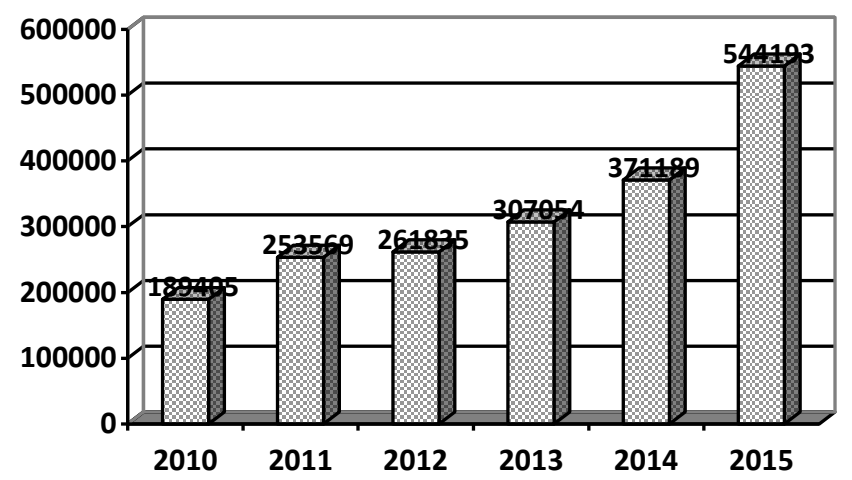

$\square$ Gross Agricultural Output of Ukraine, mIn UAH

Figure 10. The Dynamics of the Gross Agricultural Output of Ukraine, mln UAH

Source: author's elaboration on the basis of the data from the State Statistic Service of Ukraine ${ }^{16}$

The data presented in Figure 10 show the clear upward trend in the dynamics of the gross agricultural output in Ukraine. In 2011 the said indicator was $64164 \mathrm{mln}$ UAH or $34 \%$ higher than in 2010. Afterwards the tendency remained stable showing the following increase - in 2012 - by $8266 \mathrm{mln}$ UAH or $3.3 \%$, in 2013 - by $45219 \mathrm{mln}$ UAH or $17.3 \%$, in 2014 - by $64135 \mathrm{mln}$ UAH or $21 \%$ and in 2015 - by $173004 \mathrm{mln}$ UAH or $46.6 \%$ if compared to that of the previous year. The calculations given above testify to the fact that agriculture is an important sector of the Ukrainian economy that is successfully developing and has even a bigger potential to develop further.

The area of the land used in agriculture comprises 42726.4 thousand hectares that is $70.8 \%$ of the total land area of Ukraine. Approximately 32540 thousand hectares of the agricultural land is used for growing agricultural crops. Thanks to certain natural advantages (e.g. geographical position of the country, the availability of natural raw materials and resources) as well as availability of relatively cheap work force, the developed transport infrastructure and the steady growing demand for food products in the world, Ukrainian agriculture is developing rapidly and has a great potential for further development. The structure of the gross agricultural output of Ukraine in the year 2015 can be seen in Figure 11

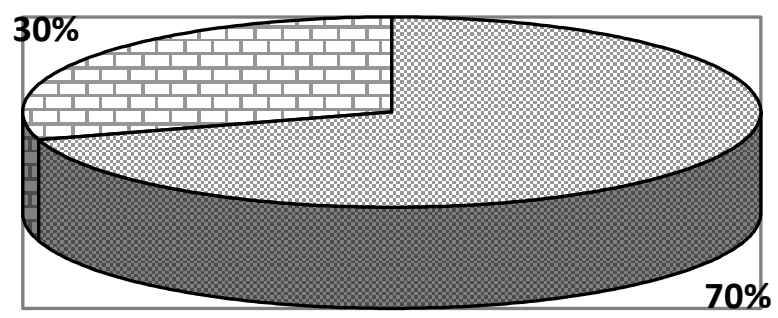

Q Plant Production

口 Livestock Production

Figure 11. The Structure of the Gross Agricultural Output of Ukraine in 2015, \%

Source: author's elaboration on the basis of the data from the State Statistic Service of Ukraine ${ }^{17}$

\footnotetext{
${ }^{16}$ Agriculture, Forestry and Fishery [Electronic resource] // Access mode: http://www.ukrstat.gov.ua/druk/publicat/kat_u/publ7_u.htm.
} 
As it is shown in the figure given above, Ukrainian agriculture is plant production oriented ( $70.3 \%$ of the total agricultural production). To further develop the research, let's analyze the gross harvest of the main agricultural crops in Ukraine (Table 2)

Table 2: The Gross Harvest of the Main Agricultural Crops in Ukraine, thousands of tons

\begin{tabular}{|l|l|l|l|l|l|l|l|l|l|}
\hline № & $\begin{array}{l}\text { Agricultural } \\
\text { Crop }\end{array}$ & $\mathbf{2 0 1 0}$ & $\mathbf{2 0 1 1}$ & $\mathbf{2 0 1 2}$ & $\mathbf{2 0 1 3}$ & $\mathbf{2 0 1 4}$ & $\mathbf{2 0 1 5}$ & $\begin{array}{l}\text { Ratio of } \\
\mathbf{2 0 1 5} \text { to } \\
\mathbf{2 0 1 0} \\
\text { thousands } \\
\text { of tons }\end{array}$ & $\begin{array}{l}\text { Ratio } \\
\text { of } \\
\mathbf{2 0 1 5} \\
\text { to } \\
\mathbf{2 0 1 0} \\
\text { \% }\end{array}$ \\
\hline 1. & $\begin{array}{l}\text { Grain and } \\
\text { Leguminous } \\
\text { Crops }\end{array}$ & 39270.9 & 56746.8 & 46216.2 & 63051.3 & 63859.3 & 60125.8 & 20854.9 & 53 \\
\hline 2 & $\begin{array}{l}\text { Sugar beet } \\
3\end{array}$ & 13749.2 & 18740.5 & 18438.9 & 10789.4 & 15734.1 & 10330.8 & -3418.4 & -25 \\
\hline 4 & $\begin{array}{l}\text { Sunflower } \\
\text { Potatoes }\end{array}$ & 6771.5 & 8670.5 & 8387.1 & 110050.5 & 10133.8 & 11181.1 & 4409.6 & 65 \\
\hline 5 & Vegetables & 8122.4 & 9832.9 & 10016.7 & 9872.6 & 9637.5 & 9214 & 1091.6 & 13 \\
\hline 6 & $\begin{array}{l}\text { Fruits and } \\
\text { Berries }\end{array}$ & 1746.5 & 1896.3 & 2008.7 & 2295.3 & 1999.1 & 2152.8 & 406.3 & 23 \\
\hline
\end{tabular}

Source: author's elaboration on the basis of the data from the State Statistic Service of Ukraine ${ }^{18}$

Having analyzed the data in Table 2, it could be affirmed that the gross harvest of all but one main agricultural crops in Ukraine increased in 2015 if compared to that of 2010. The biggest increase can be observed by sunflower production, that is 4409.6 thousand tons or $65 \%$. It should also be added that Ukraine takes the first place in the world in terms of sunflower seeds production $-27 \%$ of the total global production amount. Ukraine also takes the first place in the world in terms of the production and export of sunflower oil $-56 \%$ of the total global production amount. The second place in terms of the output increase is taken with grain and leguminous crops 20854.9 thousand tons or $53 \%$ and the third one - with fruits and berries - 406.3 thousand tons or $23 \%$.

The export structure of the agricultural and food production of Ukraine can be followed in Table 3.

The data in Table 3 allow us make the following conclusion - the export volume of all but one agricultural items increased in 2015 if compared to that of 2010. The decrease is shown only by ready food products (by $4 \%$ ). The biggest increase in the export volume showed products of plant origin - $3995.3 \mathrm{mln}$ USD or $100.5 \%$ if compared to that of the previous year. The second place is taken with fats and oils of animal or plant origin - increase by 682.5

\footnotetext{
${ }^{17}$ Agriculture, Forestry and Fishery [Electronic resource] // Access mode: https://ukrstat.org/uk/operativ/operativ2015/mp/op_u/arh_op2015.html.

${ }^{18}$ Agriculture, Forestry and Fishery [Electronic resource] // Access mode: http://www.ukrstat.gov.ua/druk/publicat/kat_u/publ7_u.htm.
} 
mln USD or $26.1 \%$ and the third - with livestock products - increase by $52 \mathrm{mln}$ USD or 6.7 $\%$ if compared to that of the year 2010. Everything mentioned above testifies to the fact that Ukraine produces enough agricultural production not only for the local consumption, but also for its export to the other countries.

Table 3: The Export Structure of the Agricultural and Food Production of Ukraine, mln USD

\begin{tabular}{|c|l|c|c|c|c|c|c|c|c|}
\hline № & & $\mathbf{2 0 1 0}$ & $\mathbf{2 0 1 1}$ & $\mathbf{2 0 1 2}$ & $\mathbf{2 0 1 3}$ & $\mathbf{2 0 1 4}$ & $\mathbf{2 0 1 5}$ & $\begin{array}{c}\text { Ratio of } \\
\mathbf{2 0 1 5} \text { to } \\
\mathbf{2 0 1 0} \\
\text { thousand } \\
\text { USD }\end{array}$ & $\begin{array}{c}\text { Ratio } \\
\text { of } \\
\mathbf{2 0 1 5} \\
\text { to } \\
\mathbf{2 0 1 0} \\
\text { \% }\end{array}$ \\
\hline 1 & Total & 9936 & 12804.1 & 17905.6 & 17038.8 & 16668.9 & 14563.1 & 4627.1 & 46.6 \\
\hline 2 & $\begin{array}{l}\text { I. } \\
\text { Livestock } \\
\text { products }\end{array}$ & 771.4 & 936.6 & 960.6 & 1084.1 & 10144.7 & 823.4 & 52 & 6.7 \\
\hline 3 & $\begin{array}{l}\text { II. } \\
\text { Products } \\
\text { of Plant } \\
\text { Origin }\end{array}$ & 3976.2 & 5532 & 9222.5 & 8875.9 & 8736.1 & 7971.5 & 3995.3 & 100.5 \\
\hline 4 & $\begin{array}{l}\text { III. Fats } \\
\text { and Oils } \\
\text { of } \\
\text { Animal } \\
\text { or Plant } \\
\text { Origin }\end{array}$ & 2617.3 & 3396.4 & 4210.6 & 3507.1 & 3822.1 & 3299.8 & 682.5 & 26.1 \\
\hline 5 & $\begin{array}{l}\text { IV. } \\
\text { Ready } \\
\text { Food } \\
\text { Products }\end{array}$ & 2571.1 & 2939.1 & 3511.9 & 3571.7 & 3096.3 & 2468.4 & -102.7 & -4 \\
\hline
\end{tabular}

Source: author's elaboration on the basis of the data from the State Statistic Service of Ukraine ${ }^{19}$.

\section{EXPORT FROM AZERBAIJAN - IMPORT TO UKRAINE}

To further develop the research, let's analyze the dynamics of goods import to Ukraine (Figure 12).

The biggest amount of the goods imported to Ukraine can be observed in 2008. A decrease of $40102.2 \mathrm{mln}$ USD or $46.8 \%$ of the said indicator followed in the year 2009. After that we see an upward trend to the year 2012 including. That is in 2010 the amount of the imported goods increased by $15309,1 \mathrm{mln}$ USD or almost $34 \%$, in 2011 - $21866 \mathrm{mln}$ USD or $36 \%$ and in 2012 - by 2049,9 mln USD or $23.8 \%$ if compared to the year before. After the year 2012 the tendency changed to the opposite one showing the decrease in the amount of the goods imported to Ukraine. In 2013 the said amount decreased by $7671.4 \mathrm{mln}$ USD or $9.1 \%$, in 2014 - by $22558.1 \mathrm{mln}$ USD or $29.3 \%$ and in 2015 - by $16912.3 \mathrm{mln}$ USD or 315 if compared to that of the previous year.

\footnotetext{
${ }^{19}$ Agriculture, Forestry and Fishery [Electronic resource] // Access mode: http://www.ukrstat.gov.ua/druk/publicat/kat_u/publ7_u.htm. 


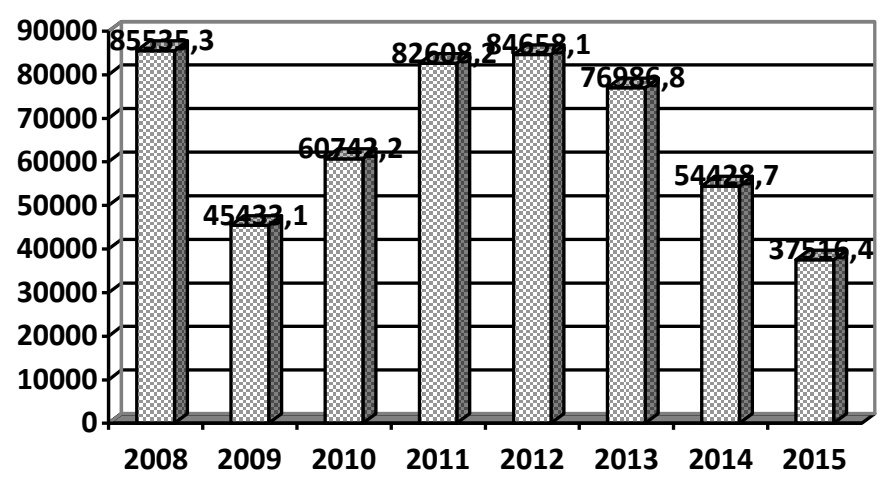

The Dynamics of Goods Import to Ukraine, mln USD

Figure 12. The Dynamics of Goods Import to Ukraine, mln USD

Source: author's elaboration on the basis of the data from the State Statistic Service of Ukraine ${ }^{20}$

In 2015 the major amount of goods was imported from the Russian Federation (20\%), Germany (10.4\%), China (10.1\%), Belarus (6.5\%), Poland $(6.2 \%)$, Hungary $(4.1 \%)$ and the USA $(3.9 \%)$.

Mineral products accounted for $31.2 \%$ of the total value of import to Ukraine, mechanical and electrical mechanisms (16.7\%), chemicals and related industries products (13.3\%), polymers, plastics and plastic articles $(7.1 \%)$, not precious metals and products from them $(5.3 \%)$, means of transport $(4.7 \%)$, ready food products $(4.3 \%)^{21}$.

The next step in the research is the analysis of the import of goods dynamics to Ukraine from Azerbaijan (Figure 13)

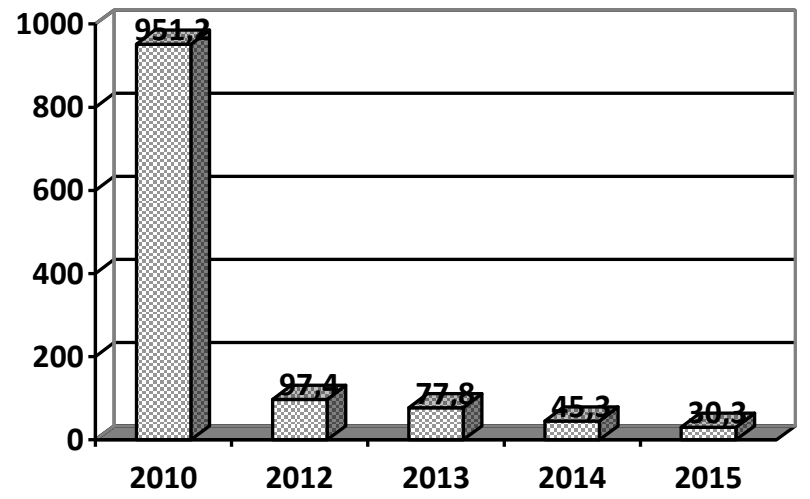

Dimport of Goods to Ukraine from Azerbaiajn, mIn USD

Figure 13. The Dynamics of Goods Import to Ukraine from Azerbaijan, mln USD

Source: author's elaboration on the basis of the data from the State Statistic Service of Ukraine ${ }^{22}$

\footnotetext{
${ }^{20}$ Foreign Trade [Electronic resource] // Access mode: https://ukrstat.org/uk/operativ/operativ2016/zd/tsztt/tsztt_u/tsztt0516_u.htm. ${ }^{21}$ Foreign Trade [Electronic resource] // Access mode: https://ukrstat.org/uk/operativ/operativ2016/zd/tsztt/tsztt u/tsztt0516 u.htm

${ }^{22}$ Ukraine's Foreign Trade in Goods [Electronic resource] // Access mode: https://ukrstat.org/uk/operativ/operativ2015/zd/tsztt/tsztt_u/tsztt1315 u.htm.
} 
It is obvious from the figure given above that the dynamics of the goods import to Ukraine from Azerbaijan has a downward trend. The biggest amount of goods was imported to Ukraine from Azerbaijan in 2010. After the said year a huge drop in the import of goods can be observed, meaning $-853.8 \mathrm{mln}$ USD or $89.8 \%$ if compared to that of the year 2010 . The next year was not an exception and showed the decrease in the amount of the goods imported to Ukraine from Azerbaijan of $19.6 \mathrm{mln}$ USD or $20.1 \%$ if compared to the previous year. In 2014 the downward tendency continued and the decrease was $32.5 \mathrm{mln}$ USD or $41.8 \%$ if compared to that of 2013. The last year under research showed the decrease in the amount of the imported goods of $15 \mathrm{mln}$ USD or $33.1 \%$.

In 2015 the main import items to Ukraine from Azerbaijan were the following ones: mineral fuels, oil and products from it - $28 \%$ (decrease of $29.6 \%$ if compared to the previous year), plastics and polymer materials - $25.6 \%$ (decrease of $48.5 \%$ ), goods purchased in ports $15.5 \%$ (increase of $20 \%$ ), edible fruit and nuts - $7.4 \%$ (decreased by $21 \%$ ); organic chemical compounds $-7.2 \%$ (increased by $51.2 \%)^{23}$.

The main commodity groups of goods export from Azerbaijan in 2015 were mineral products $(86.6 \%)$, vegetables $(2.9 \%)$, food products, beverages, spirits and vinegar, tobacco $(2.4 \%)$, fats and oils of animal and vegetable origin $(1.3 \%)$, miscellaneous articles of base metal (1.2 $\%)$, plastic, rubber and articles (1\%), products of chemical industry $(0.7 \%)$ and machine, electrical technological equipment $(0.5 \% \text { of the total export amount })^{24}$.

Having compared the goods mostly exported from Azerbaijan and those Ukraine import, the following items are to be the ones of common interest for both countries: mineral products, miscellaneous articles of base metal, plastic, rubber and articles and products of chemical industry. That is the items that were already imported to Ukraine from Azerbaijan and the import volume of most of them decreased in the period under research. It means, the way to cooperation in the direction export from Azerbaijan - import to Ukraine, that lies in the industrial sector of economy, does not have much potential in itself.

So, the best way to foster cooperation in terms of foreign trade is in the direction export from Ukraine - import to Azerbaijan and it is agriculture and food production industry.

We can observe the first steps of improving economic relations between Ukraine and Azerbaijan in terms of Azerbaijani investment into the economy of Ukraine (Figure 14)

\footnotetext{
${ }^{23}$ Analytical Information on Foreign Trade Statistics of the Republic of Azerbaijan [Electronic resource] // Access mode: http://www.ved.gov.ru/files/images/country/Azerbaijan/2015/Analytical\%20information\%20on\%20foreign\%20trade \%20statistics\%20of\%20the\%20Republic\%20of\%20Azerbaijan\%20in\%202014.pdf.

${ }^{24}$ Azerbaijan in figures [Electronic resource] // Access mode: http://www.stat.gov.az/menu/6/statistical_yearbooks/indexen.php.
} 

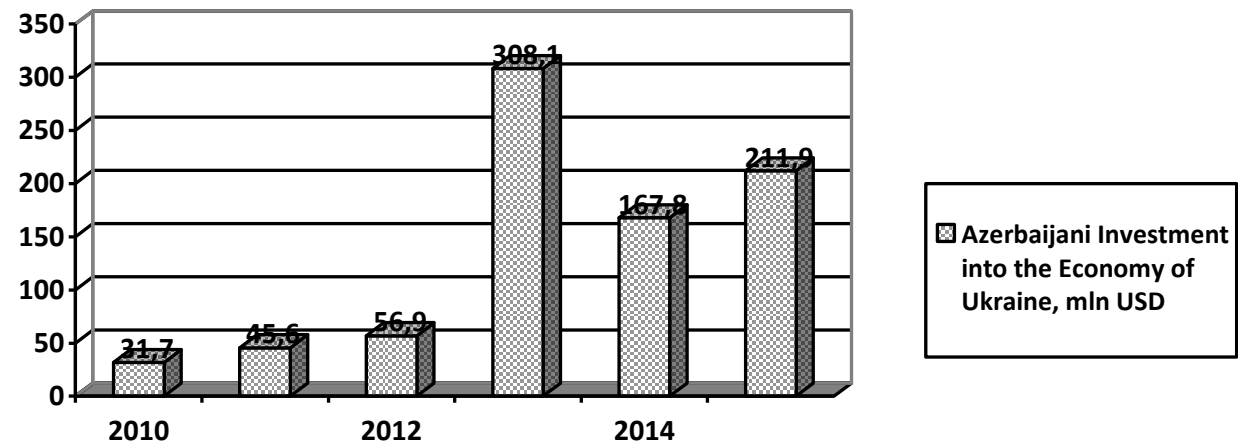

Figure 14. The Dynamics of Azerbaijani Investment into the Economy of Ukraine, mln USD Source: author's elaboration on the basis of the data from the Embassy of Ukraine in the Republic of Azerbaijan ${ }^{25}$.

As we see in Figure 14, from 2010 to 2013 including there was an upward trend in the Azerbaijani investment into the economy of Ukraine. In 2011 the said investment increased by $13.9 \mathrm{mln}$ USD or $43.8 \%$ if compared to that of 2010. In the following year the increase was $11.3 \%$ or $24.8 \%$ in comparison to the previous one. The biggest increase in the volume of the Azerbaijani investment into the Ukrainian economy was in the year 2013 and comprised $251.2 \mathrm{mln}$ USD or $441.5 \%$. But after the said year we observe a decrease in the investment mentioned above of $140.1 \mathrm{mln}$ USD or $45.5 \%$ if compared to that of the year 2013. The situation improved in 2015 showing the increase of the investment of $45.1 \mathrm{mln}$ USD or almost $27 \%$. The amount of the Azerbaijani investment into the economy of Ukraine didn't reach the level of the year 2013 but the positive trend in its dynamics points to the improving of the economic relations between Ukraine and Azerbaijan.

\section{CONCLUSIONS}

The importance of the political and economic cooperation with the countries of the Asian region is defined with its role of the locomotive of the global economy and one of the driving forces of the global development. Euro - Asian cooperation contributes to a significant expansion of the multifaceted relations between the countries of the two continents.

An important direction of the Ukrainian politics and economics, pointed at the modernization of the state, is not only the European but also the Asian one. Because of its geographical position Ukraine could be the bridge between East and West.

The economic situation of Ukraine cannot be described as a stable one. Together with the improvement of some indicators characterizing its economic development, some of them show the decrease in their numerical expression. That is, together with the upward trend in the GDP of the country and GDP per capita, the FDI into the economy of Ukraine decreased during the last two years. The explanation of such a state of affairs may be the unstable political situation and the changes in the financial sector of the economy of the country which make the foreign investors be more careful while investing into the Ukrainian economy. So, one of the main tasks for Ukraine nowadays is to make the Ukrainian economy more attractive for foreign investors as the increase of FDI positively affect the balance of

\footnotetext{
${ }^{25}$ Trade and Economic Relations of Ukraine and Azerbaijan [Electronic resource] // Access mode: http://azerbaijan.mfa.gov.ua/ru/ukraine-az/trade.
} 
payments, the level of employment in the country and contribute to its further economic development.

One of the ways to improve an unstable economic situation of a country is to increase the amount of its exports as it usually provides the country with foreign currency, stabilizes its positions on the foreign markets, creates new jobs inside it, etc. In such a situation, one can either search for new trade partners or have a closer look at the existing ones, seeking new ways of cooperation for the mutual benefits of both countries. Such a partner for Ukraine, which is worth paying attention at, is Azerbaijan, though the present state of affairs between the two countries in terms of foreign trade is far away from being optimistic.

The decrease in the amount of goods exports from Ukraine to Azerbaijan may be explained by the decrease in the exports of ferrous metals and their products because of the anti terrorist operation in the eastern regions of Ukraine where the main industrial enterprises functioning in the metallurgical sector were situated.

So, the items that are to be the ways of fostering cooperation in terms of foreign trade between Ukraine and Azerbaijan in the direction export from Ukraine - import to Azerbaijan are the ones connected with agriculture, that is foodstuffs, products of vegetable and animal origin, fats and oils of animal or vegetable origin. They are the items that take big share in the amount of goods exports from Ukraine and, at the same time, the big shares in the amount of goods imports to Azerbaijan.

The research made in the article testifies to the fact that Ukraine produces enough agricultural production not only for the local consumption, but also for its export to the other countries.

Having compared the goods mostly exported from Azerbaijan and those Ukraine import, the following items are to be the ones of common interest for both countries: mineral products, miscellaneous articles of base metal, plastic, rubber and articles and products of chemical industry. That is the items that were already imported to Ukraine from Azerbaijan and the import volume of most of them decreased in the period under research. It means, the way to cooperation in the direction export from Azerbaijan - import to Ukraine, that lies in the industrial sector of economy, does not have much potential in itself.

But, in spite of some difficulties, it is possible to forecast that, the cooperation between European and Asian countries, in our case - between Ukraine and Azerbaijan, will be strengthened because of the constant growth of interest to the said cooperation from both sides. The said cooperation will provide the opportunity to develop the long - term plans for economic cooperation, to timely grasp and respond to the economic needs and opportunities of the two regions, to rebuild the system of priorities in the foreign economic activities of the countries and to be ready for any regional or global economic changes. All in all, mutually beneficial cooperation between Ukraine and Azerbaijan will significantly strengthen the political and economic positions of both countries on the world arena. 


\section{REFERENCES}

AGRICULTURE, FORESTRY AND FISHERY [Electronic resource] // Access mode: https://ukrstat.org/uk/operativ/operativ2015/mp/op_u/arh_op2015.html. Downloaded 14.01.2017.

AGRICULTURE, FORESTRY AND FISHERY [Electronic resource] // Access mode: http://www.ukrstat.gov.ua/druk/publicat/kat_u/publ7_u.htm.

Downloaded 15.01.2017.

AGROPOLIT.COM [Electronic resource] // Access mode: https://agropolit.com/news/172ukrayina-na-8-mistsi-u-reytingu-nayrozvinutishih-agrarnih-krayin. Downloaded 15.01.2017.

ANALYTICAL INFORMATION ON FOREIGN TRADE STATISTICS OF THE REPUBLIC OF AZERBAIJAN [Electronic resource] // Access mode: http://www.ved.gov.ru/files/images/country/Azerbaijan/2015/Analytical\%20informa tion $\% 20$ on $\% 20$ foreign $\% 20$ trade $\% 20$ statistics $\% 20$ of $\% 20$ the $\% 20$ Republic $\% 20$ of $\% 20$ Azerbaijan\%20in\%202014.pdf. Downloaded 17.01.2017.

AZERBAIJAN [Electronic resource] $/ /$ Access mode: http://atlas.media.mit.edu/en/profile/country/aze/\#Imports. Downloaded 22.12.2016.

AZERBAIJAN IMPORT [Electronic resource] // Access mode: http://atlas.media.mit.edu/en/profile/country/aze/\#Imports. Downloaded 10.01.2017.

AZERBAIJAN IN FIGURES [Electronic resource] // Access mode: http://www.stat.gov.az/menu/6/statistical_yearbooks/indexen.php. Downloaded 17.01.2017.

COMMODITY STRUCTURE OF FOREIGN TRADE [Electronic resource] // Access mode: https://ukrstat.org/uk/operativ/operativ2015/zd/tsztt/tsztt_u/tsztt1315_u.htm.

Downloaded 09.01.2017.

FOREIGN TRADE [Electronic resource] // Access mode: https://ukrstat.org/uk/operativ/operativ2016/zd/tsztt/tsztt_u/tsztt0516_u.htm.

Downloaded 14.01.2017.

TRADE AND ECONOMIC RELATIONS OF UKRAINE AND AZERBAIJAN [Electronic resource] // Access mode: http://azerbaijan.mfa.gov.ua/ru/ukraine-az/trade. Downloaded 09.01.2017.

UKRAINE [Electronic resource] // Access mode: https://ukrstat.org/uk/druk/publicat/kat_u/publ1_u.htm. Downloaded 06.01.2017.

UKRAINE - 215 [Electronic resource] // Access mode: https://ukrstat.org/uk/druk/publicat/kat_u/publ1_u.htm]. Downloaded 05.01.2017.

UKRAINE IN FIGURES [Electronic resource] // Access mode: https://ukrstat.org/uk/druk/publicat/kat_u/publ1_u.htm. Downloaded 05.01.2017.

UKRAINE'S FOREIGN TRADE IN GOODS [Electronic resource] // Access mode: https://ukrstat.org/uk/operativ/operativ2015/zd/tsztt/tsztt_u/tsztt1315_u.htm.

Downloaded 09.01.2017. 